Global Conferences Series:

Sciences and Technology (GCSST), Volume 5, 2020

Seminar Nasional I Baristand Industri Padang (Semnas I BIPD)

DOI: https://doi.org/10.32698/GCS-SNIIBIPD3440

\title{
The effect of green industry application on greenhouse gas emissions in the industrial activities in Indonesia
}

\section{Pengaruh penerapan industri hijau terhadap emisi gas rumah kaca kegiatan industri di Indonesia}

\author{
Ignacius Dhani Sukaryono \\ Balai Riset dan Standardisasi Industri Ambon, Indonesia \\ E-mail: ignacdhani@gmail.com
}

\begin{abstract}
Global warming is mainly caused by an increase in the concentration of greenhouse gases $(G H G)$ as a result of human activities. CO2 emissions have increased due to industrial advancement that is directly proportional to energy consumption. The green industry is one of the efforts to reduce the increase in GHG emissions. The green industry implementation in Indonesia was initiated in 2010 through a green industry award. This study aims to determine the effect of the green industry in Indonesia on GHG emissions in industrial activities. The research method used in research is a descriptive quantitative method with a secondary data analysis. The results showed that there were a few effects (5.1\%) of the green industry on reducing total GHG emissions in industrial activities. The GHG emission in the manufacturing energy sector has decreased which is influenced by the implementation of the green industry with an effectiveness value of $68.2 \%$. The opposite effect occurs in the IPPU (Industrial Processes and Product Use) and waste sectors. The green industry increases GHG emissions in the IPPU sector with an effect of $92.4 \%$, while it has an effect of $81 \%$ in increased GHG emissions in the waste sector. The green industry has not had a significant effect on reducing GHG emissions in industrial activities. This is due to the small number of industries that apply the green industry concept. The implementation of the green industry must begin to shift from voluntary to mandatory so that it can affect reducing $G H G$ emissions.
\end{abstract}

Keywords:green industry; greenhouse gas emissions; CO2

\begin{abstract}
Abstrak:Pemanasan global terjadi oleh adanya peningkatan konsentrasi gas-gas rumah kaca (GRK) akibat dari aktivitas manusia melalui efek rumah kaca. Emisi $\mathrm{CO} 2$ meningkat drastis yang disebabkan oleh semakin majunya industri yang berbanding lurus dengan konsumsi energi. Penerapan industri hijau merupakan salah satu upaya untuk menekan peningkatan emisi GRK. Penerapan industri hijau di Indonesia dirintis sejak tahun 2010 melalui penghargaan industri hijau. Penelitian ini bertujuan untuk mengetahui pengaruh penerapan industri hijau di Indonesia terhadap emisi GRK pada kegiatan industri. Metode penelitian yang digunakan yaitu metode penelitian kuantitatif deskriptif dengan pendekatan Analisis Data Sekunder (ADS). Hasil penelitian menunjukkan bahwa adanya pengaruh yang kecil (5,1\%) penerapan industri hijau terhadap penurunan emisi GRK total kegiatan industri. Emisi GRK sektor energi manufaktur mengalami penurunan yang dipegaruhi oleh penerapan industri hijau dengan nilai pengaruh sebesar 68,2\%. Pengaruh yang berlawanan terjadi pada sektor IPPU (Industrial Processes and Product Use) dan limbah. Penerapan industri hijau meningkatkan emisi GRK sektor IPPU dengan pengaruh sebesar 92,4\%, sedangkan berpengaruh sebesar $81 \%$ dalam peningkatan emisi GRK sektor limbah. Penerapan industri hijau belum terlalu signifikan berpengaruh terhadap penurunan emisi GRK pada kegiatan industri. Penerapan industri hijau harus mulai beralih dari voluntary menjadi mandatory sehingga dapat berpengaruh dalam penurunan emisi GRK
\end{abstract}

Kata kunci:industri hijau; emisi gas rumah kaca; $\mathrm{CO} 2$

Copyright (C) 2020, the Authors. Published by Redwhite Press.

This is an open access article under the CC BY-NC license

(http://creativecommons.org/licenses/by-nc/4.0). 


\section{PENDAHULUAN}

Pemanasan global merupakan isu yang telah lama berkembang sejak era pra industri dan perkembangan pesat bidang transportasi dan teknologi (Baiquni, 2009). Fenomena ini dikaitkan dengan adanya peningkatan temperatur rata-rata permukaan bumi (Karyono, 2007). Peningkatan suhu bumi sebenarnya sudah terjadi sejak 20.000 tahun yang lalu (zaman gletser). Peningkatan suhu bumi terjadi sangat lambat hingga akhir abad 18 yaitu rata-rata peningkatannya hanya $0,2^{\mathrm{O}} \mathrm{C}$ (Suwedi, 2005; Karyono, 2007). Temperatur rata-rata global berdasarkan catatan IPCC (Intergovernmental Panel of Climate Change) telah meningkat sebesar $0,78^{\circ} \mathrm{C}$ antara rentang tahun 1900-2000 (Kusminingrum, 2008). Peningkatan suhu bumi ini telah memicu berbagai perubahan kondisi bumi seperti pencairan es di daerah kutub dan gletser yang menyebabkan peningkatan tinggi permukaan laut serta pelepasan gas-gas beracun. Selain itu juga adanya perubahan iklim yang kemudian dapat mempengaruhi kelangsungan hidup manusia dan makhluk hidup lain di muka bumi seperti terjadinya kekeringan yang dapat berdampak pada ketahanan pangan; kebakaran hutan; peningkatan hujan badai dan banjir; merebaknya berbagai penyakit (Triana, 2008; Waryono, 2008; Latuconsina, 2010).

Pemanasan global yang terjadi dipengaruhi oleh beberapa hal seperti fluktuasi radiasi gelombang elektromagnetik matahari dan yang paling utama adanya fenomena efek rumah kaca. Efek rumah kaca atau Greenhouse Effect merupakan selisih antara radiasi permukaan bumi yang dipancarkan ke luar angkasa seandainya tidak ada atmosfer dengan radiasi permukaan bumi yang sesungguhnya dipancarkan ke luar angkasa (Sugiyono, 2006). Efek rumah kaca ini terjadi karena adanya gas-gas yang menyerap dan memancarkan radiasi infrared yang kemudian disebut dengan gas-gas rumah kaca. Gas-gas rumah kaca terdiri dari uap air yang mempengaruhi terbentuknya efek rumah kaca sebesar 36-70\%, karbon dioksida $\left(\mathrm{CO}_{2}\right)$ yang pengaruhnya sebesar $9-25 \%$, metana $\left(\mathrm{CH}_{4}\right)$ yang pengaruhnya sebesar $4-9 \%$ dan ozon $\left(\mathrm{O}_{3}\right)$ yang pengaruhnya sebesar $3-7 \%$ serta gas-gas lainnya seperti dinitrogen oksida $\left(\mathrm{N}_{2} \mathrm{O}\right)$, halo karbon atau fluorocarbon $\left(\mathrm{C}_{\mathrm{x}} \mathrm{F}_{\mathrm{y}}\right)$, sulfur heksafluorida $\left(\mathrm{SF}_{6}\right)$, nitrogen trifluorida $\left(\mathrm{NF}_{3}\right)$ dan gas-gas prekursor (karbon dioksida/CO, nitrogen oksida/ $\mathrm{NO}_{\mathrm{x}}$ dan volatile organic compounds/VOC). Gas rumah kaca yang ada di permukaan bumi didominasi oleh $\mathrm{CO}_{2}$ yang sebesar $76 \%, \mathrm{CH}_{4}, 13 \%, \mathrm{~N}_{2} \mathrm{O} 6 \%$ dan $\mathrm{C}_{\mathrm{x}} \mathrm{F}_{\mathrm{y}}$ sebesar $5 \%$ (Cahyono, 2007;SOS, 2011; Anggraeni, 2015; Muryani, 2018).

Berdasarkan data World Resources Institute (WRI) emisi gas rumah kaca (GRK) terus meningkat dari tahun ke tahun (Gambar 1). Secara global emisi GRK meningkat sebesar 41\% selama rentang tahun 19902016. Emisi GRK di Indonesia juga mengalami peningkatan sebesar $48 \%$ pada rentang tahun yang sama. Emisi GRK Indonesia pada tahun 2016 menempati posisi kedelapan dunia dengan prosentase 1,88\% dari nilai emisi GRK secara global. Emisi GRK dari 10 negara (China, Amerika Serikat, Uni Eropa, India, Rusia, Jepang, Brazil, Indonesia, Iran dan Korea Selatan) terbanyak mencapai 68\% dari emisi GRK global.

Emisi GRK setiap tahun diinventarisasi secara nasional oleh Direktorat Inventarisasi Gas Rumah Kaca dan MPV, Direktorat Jenderal Pengendalian Perubahan Iklim, Kementerian Lingkungan Hidup dan Kehutanan. Inventarisasi GRK ini bertujuan untuk menyajikan data dan informasi mengenai profil GRK di Indonesia yang kemudian dapat dijadikan bahan pertimbangan dalam penyusunan kebijakan dalam melakukan mitigasi perubahan iklim. Metodologi yang digunakan untuk menghitung emisi GRK mengacu pada metode yang ditetapkan oleh Intergovernmental Panel of Climate Change (IPCC). Perhitungan emisi GRK dilakukan pada 4 sektor yaitu sektor energi, sektor Industrial Processes and Product Use (IPPU), sektor pertanian, kehutanan dan penggunaan lahan lainnya (AFOLU/Agriculture, Forestry and Other Land Use), dan sektor limbah (Kementerian Lingkungan Hidup dan Kehutanan, 2019). Kegiatan industri ikut menyumbang dalam perhitungan inventarisasi emisi GRK pada sektor energi, sektor IPPU dan sektor limbah. Kontribusi emisi GRK dari kegiatan industri pada tahun 2018 sebesar 15\% dari total emisi GRK di Indonesia. Hal tersebut menunjukkan bahwa kegiatan industri cukup berpengaruh pada fenomena perubahan iklim.

Strategi yang dilakukan dalam upaya mitigasi perubahan iklim dan memenuhi target Nationally Determined Contribution (NDC) Indonesia sebesar 29\% dengan upaya sendiri dan menjadi $41 \%$ dengan dukungan kerja sama internasional dari kondisi tanpa ada aksi (business as usual/BAU) pada tahun 2030 yang sekaligus menerapkan pembangunan berkelanjutan dan mendukung konvensi dan perjanjian internasional (Protokol Kyoto: Perubahan Iklim, Deklarasi Rio: Pembangunan Berkelanjutan, Deklarasi Manila dan Paris Climate Conference: Perubahan Iklim) maka perlu diambil langkah-langkah terutama dalam bidang industri seperti penerapan konsep industri hijau (Aminah and Yusriyadi, 2018). Definisi industri hijau menurut UU No. 3/2014 tentang Perindustrian merupakan industri yang dalam proses produksinya mengutamakan upaya efisiensi dan efektivitas penggunaan sumber daya secara berkelanjutan 
sehingga mampu menyelaraskan pembangunan industri dengan kelestarian fungsi lingkungan hidup serta dapat memberi manfaat bagi masyarakat (Indonesia, 2014).

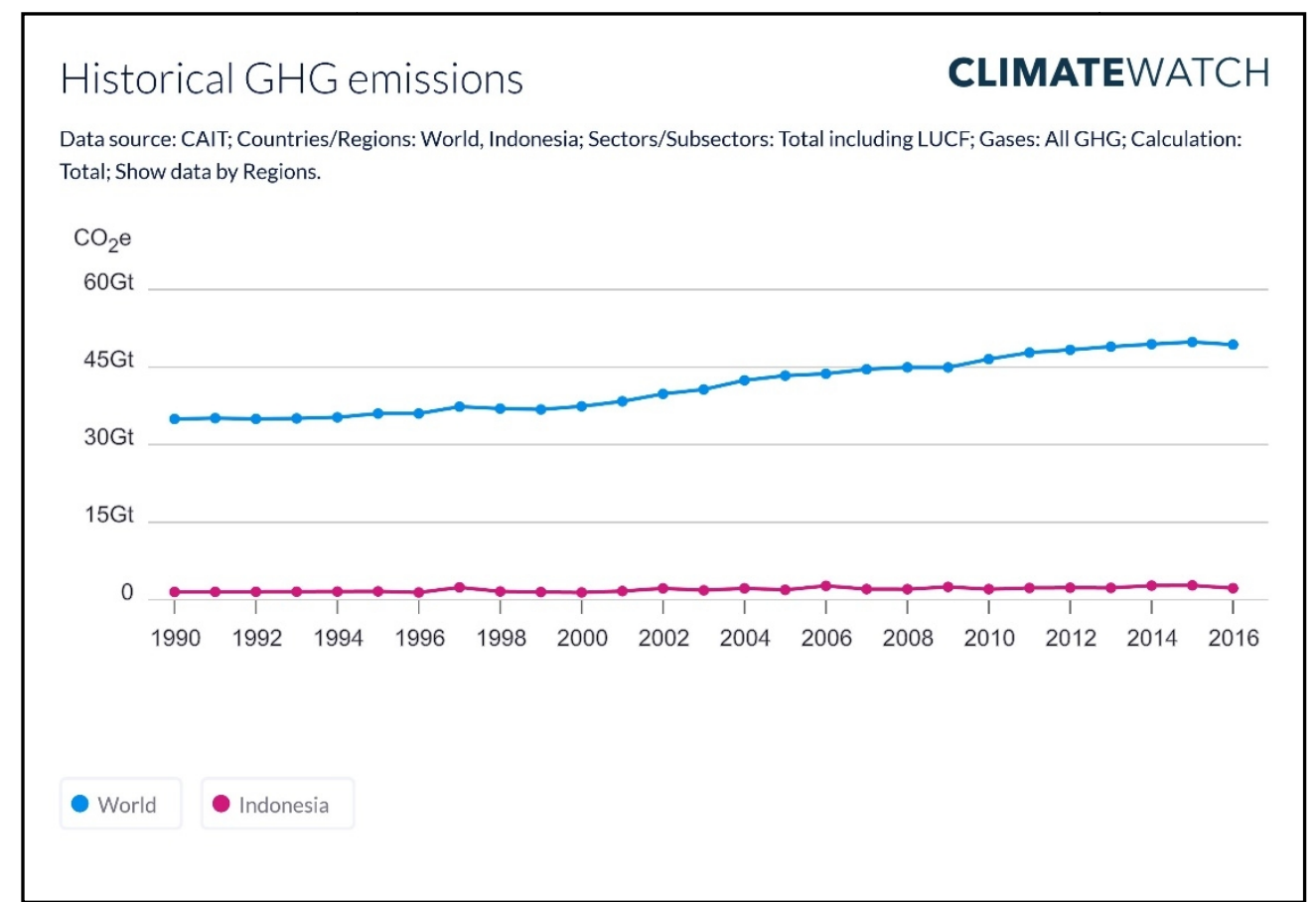

Gambar 1. Profil Emisi Gas Rumah Kaca (GRK) Indonesia dan Dunia Tahun 1990-2016 (World Resources Institute, 2017)

Strategi pengembangan industri hijau melalui dua acara yaitu Greening of Existing Industries (mengembangkan industri yang sudah ada menuju industri hijau) dan Creation of New Green Industries (membangun industri baru dengan prinsip industri hijau). Kedua strategi tersebut dilakukan melalui pemberian penghargaan industri hijau dalam rangka menyiapkan industri yang tersertifikasi industri hijau. Penghargaan industri hijau telah berjalan sejak tahun 2010 dengan jumlah penerima penghargaan sebanyak 895 industri sampai tahun 2019 baik dari industri skala kecil, menengah dan besar. Tahun 2017 mulai dilakukan sertifikasi industri hijau yang bersifat voluntary (sukarela) dan secara bertahap akan diberlakukan wajib (mandatory). Industri yang secara sukarela menerapkan konsep industri hijau oleh pemerintah akan diberikan fasilitas berupa fiskal (perpajakan, kepabean dan keringanan kredit) dan non-fiskal (pengembangan industri hijau, promosi dan informasi serta capacity building).

Berdasarkan pada latar belakang dan permasalahan yang ada perlu dilakukan kajian mengenai proses penerapan konsep industri hijau di Indonesia dan profil emisi GRK pada kegiatan industri di Indonesia serta hubungan keduanya. Penelitian ini bertujuan untuk mengetahui pengaruh penerapan industri hijau di Indonesia terhadap emisi GRK pada kegiatan industri di Indonesia. Hasil dari penelitian ini diharapkan dapat menjadi bahan pertimbangan dalam mengambil keputusan dan kebijakan terutama dalam bidang industri hijau sebagai salah satu langkah mitigasi perubahan iklim dan juga peningkatan efisiensi dan efektivitas dalam proses produksi.

\section{METODE}

Penelitian ini menggunakan metode penelitian kuantitatif deskriptif dengan pendekatan Analisis Data Sekunder (ADS). ADS merupakan suatu metode dengan memanfaatkan data sekunder sebagai sumber data utama. Memanfaatkan data sekunder yang dimaksud yaitu dengan menggunakan teknik uji statistik yang sesuai untuk mendapatkan informasi yang diinginkan dari data yang sudah matang yang diperoleh pada instansi atau lembaga tertentu untuk kemudian diolah secara sistematis dan obyektif (Sugiyono, 2018). Data yang diperoleh berupa data kuantitatif berupa data jumlah perusahaan yang menerima penghargaan industri hijau dan perusahaan yang memperoleh sertifikasi industri hijau pada rentang tahun 2010-2019 serta datadata pelengkap yang berhubungan dengan industri hijau. Data-data tersebut didapatkan dari Pusat Industri Hijau, Kementerian Perindustrian. Data yang lainnya yaitu data emisi GRK yang dihasilkan Indonesia dari 
tahun 1990-2018 yang berasal dari data inventarisasi GRK dan statistika Direktorat Jenderal Pengendalian Perubahan Iklim, Kementerian Lingkungan Hidup dan Kehutanan. Selain itu juga data emisi GRK diperoleh dari WRI.Dalam penelitian ini data variabel yang dipakai yaitu data jumlah industri penerima Penghargaan Industri Hijau (PIH) sebagai variabel independen dan data jumlah emisi GRK kegiatan industri sebagai variabel dependen. Variabel dependen yang digunakan terbagi dalam 4 jenis yaitu data emisi GRK kegiatan industri secara total, data emisi GRK kegiatan industri dari sektor energi, data emisi GRK kegiatan industri dari sektor IPPU dan data emisi GRK kegiatan industri dari sektor limbah.

Metode analisis data yang digunakan dalam penelitian ini terdiri dari analisis secara deskriptif dan analisis korelasi. Analisis data secara deskriptif bertujuan untuk mendeskripsikan atau menggambarkan data perkembangan industri hijau dan emisi GRK di Indonesia dalam rentang tahun tertentu. Sedangkan analisis korelasi digunakan dalam penelitian dengan tujuan mengetahui hubungan antara variabel jumlah industri yang sudah menerapkan industri hijau melalui program Penghargaan Industri Hijau (PIH) dan variabel emisi GRK pada kegiatan industri baik secara total maupun per sektor. Analisis korelasi dilakukan dengan menggunakan bantuan pengangkat lunak IBM SPSS Statistics 25 dengan menggunakan analisis bivariate: Pearson's Correlation Coefficient. Analisis korelasi bivariate Pearson ini mempunyai persyaratan yang harus dipenuhi yaitu data harus bersifat data kuantitatif atau metrik, data harus berdistribusi normal, dan terdapat hubungan yang linier. Adapun syarat-syarat tersebut dapat dipenuhi dengan melakukan langkahlangkah seperti yang pertama yaitu eksplorasi data yang bertujuan untuk mengetahui sebaran data apakah linier atau tidak dan bagaimana polanya dengan memplot data dalam bentuk grafik atau chart. Langkah kedua yaitu uji normalitas yang dilakukan dengan melihat nilai Sig (p-value) pada Kolmogorov-Smirnov dan Shapiro-Wilk yang bertujuan untuk mengetahui data terdistribusi normal atau tidak. Data terdistribusi normal jika nilai Sig. (p-value)>0,05.

Langkah ketiga yaitu perhitungan Nilai Koefisien Korelasi (r) yang bertujuan untuk mengetahui derajat hubungan atau keterkaitan antara variabel-variabelnya. Keterkaitan atau hubungan yang ada ditunjukkan dengan besaran koefisien korelasi (r) yang nilainya antara $-1<\mathrm{r}<1$. Koefisien korelasi yang semakin mendekati nilai 0 menunjukkan korelasi yang lemah atau rendah sedangkan koefisien korelasi yang mendekadi nilai 1 baik negatif maupun positif menunjukkan korelasi yang kuat atau tinggi, nilai negatif atau positif menunjukkan arah yang sama atau berlawanan. Langkah keempat yaitu pengujian hipotesis yang bertujuan untuk mengetahui apakah terdapat hubungan linier atau tidak pada variabel-variabel yang diuji dan dasar dalam membuat keputusan yang dapat dilakukan dengan dua cara. Cara yang pertama yaitu berdasarkan nilai mutlak t-hitung, jika nilai mutlak t-hitung $>$ t-tabel maka terdapat korelasi antar variabel yang dihubungkan dan begitu sebaliknya. Cara kedua yaitu berdasarkan nilai $r$ hitung (Pearson Correlations), jika nilai mutlak $\mathrm{r}$ hitung $>\mathrm{r}$ tabel kritis maka terdapat korelasi antar variabel yang dihubungkan dan begitu sebaliknya. Selanjutnya langkah terakhir yaitu perhitungan Koefisien Determinasi (r2) yang bertujuan untuk mengetahui proposisi keragaman yang dapat diterangkan atau dijelaskan oleh hubungan linier antara variabel-variabelnya.

\section{HASIL DAN PEMBAHASAN \\ Perkembangan Penerapan Industri Hijau di Indonesia}

Penerapan konsep industri hijau di Indonesia sebenarnya sudah berlangsung sejak lama yaitu berawal dari adanya Undang-Undang Nomor 5 Tahun 1984 tentang Perindustrian. Dalam salah satu pasalnya, memuat bahwa pembangunan industri harus berlandaskan pada kelestarian lingkungan hidup. Deklarasi Manila mengenai industri hijau di Asia pada tahun 2009 menjadi sebuah perjanjian secara hukum tetapi tidak mengikat untuk pengembangan industri sebagai salah satu langkah dalam adaptasi dan mitigasi terhadap perubahan iklim. Deklarasi ini menjadikan suatu kesepakatan bersama negara-negara Asia yang harus diwujudkan melalui pengembangan industri hijau. Oleh sebab itu, pada tahun 2010 Indonesia mulai mewujudkan agenda kesepakatan dalam Deklarasi Manila tersebut melalui pemberian PIH. Penghargaan ini diberikan kepada perusahaan-perusahaan yang telah menerapkan prinsip industri hijau dalam proses produksinya. PIH ini masih berlangsung hingga sekarang dan sebanyak 895 perusahaan telah mendapat PIH pada periode tahun 2010-2019. Penilaian yang dilakukan terdiri dari 3 komponen penilaian yaitu proses produksi $(70 \%)$, pengolahan limbah/emisi $(20 \%)$ dan manajemen perusahaan $(10 \%)$. Industri yang dapat berpartisipasi dalam penghargaan tersebut tidak hanya dari industri skala besar, tetapi industri kecil dan menengah juga dapat ikut ambil bagian dalam program penghargaan tersebut.

Undang-Undang Nomor 3 Tahun 2014 tentang Perindustrian mengatur implementasi industri hijau di Indonesia melalui perumusan kebijakan, penguatan kapasitas kelembagaan, standardisasi dan pemberian fasilitas. Menindaklanjuti implementasi industri hijau tersebut, pada tahun 2017 dilakukan sertifikasi industri hijau untuk pertama kalinya. Industri yang dinyatakan memenuhi standar industri hijau oleh lembaga 
sertifikasi industri hijau sebanyak 5 industri. Sertifikasi industri hijau yang kedua diadakan pada tahun 2018 dengan sebanyak 9 industri dinyatakan memenuhi standar industri hijau. Pada tahun yang sama dikeluarkanlah Peraturan Pemerintah Nomor 29 Tahun 2018 tentang Pemberdayaan Industri yang mengatur lebih rinci mengenai standar industri hijau dan sertifikasi industri hijau. Sertifikasi industri hijau yang ketiga diadakan pada tahun 2019 dengan sebanyak 17 industri dinyatakan memenuhi standar industri hijau dengan pembiayaan pemerintah dan 2 industri dinyatakan memenuhi standar industri hijau dengan pembiayaan oleh industri sendiri. Standar Industri Hijau (SIH) yang ditetapkan pada tahun 2020 sebanyak 5 standar sehingga total sudah ada sebanyak 18 SIH yang telah ditetapkan dan masih akan terus ditambah SIH untuk industri yang lainnya.

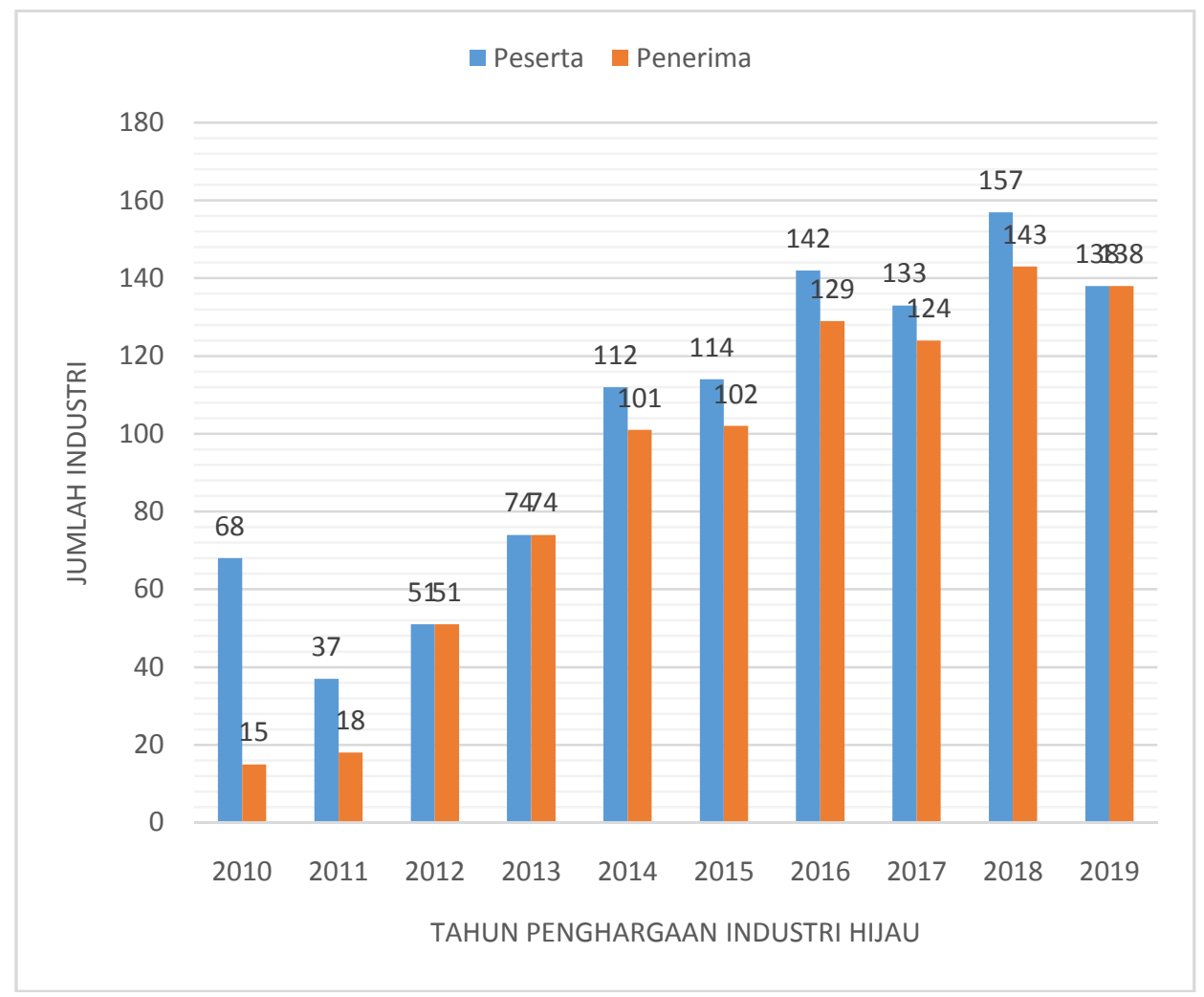

Gambar 2.Grafik Jumlah Industri Peserta dan Penerima Program Penghargaan Industri Hijau Tahun 2010-2019 (Pusat Industri Hijau, Kementerian Perindustrian; 2020)

PIH terus diadakan setiap tahunnya dengan kepesertaanya secara sukarela (voluntary). Jumlah industri yang berperan serta dalam PIH terus meningkat dari tahun ke tahunnya (Gambar 2). PIH pertama (2010) diikuti oleh 68 industri dengan penerima penghargaan hanya 15 industri atau $22 \%$ dari jumlah peserta. Keikutsertaan industri meningkat drastis pada PIH tahun 2018 dengan 157 industri yang berpartisipasi dengan tingkat penerima penghargaan sekitar $91 \%$ atau 143 industri yang menerima PIH. Tingkat penerima PIH mencapai 100\% (industri yang berpartisipasi menerima semua PIH) terjadi pada PIH pada tahun 2019, meskipun kepesertaannya menurun dari tahun sebelumnya. Secara keseluruhan pelaksanaan PIH terus mengalami peningkatan dari segi kepesertaanya. Hal ini menunjukkan bahwa industri-industri di Indonesia mulai aktif dalam penerapan industri hijau sebagai langkah dalam peningkatan efisiensi dan efektivitas pada proses produksi. Selain itu juga sebagai salah satu langkah mitigasi perubahan iklim dan pelestarian lingkungan hidup. Program PIH juga memberikan manfaat berupa penghematan di sektor energi dan penggunaan air. Penghargaan industri hijau tahun 2019 secara kalkulasi memberikan penghematan energi setara Rp. 3,5 Triliun dan penghematan air setara Rp. 228,9 Miliar. Angka penghematan ini naik dari tahuntahun sebelumnya yaitu pada tahun 2018 terdapat penghematan energi setara Rp. 1,8 Triliun, penghematan air setara 27 Miliar dan pada tahun 2017 terdapat penghematan energi setara Rp. 2,8 Triliun, penghematan air setara Rp. 96 Miliar. 


\section{Profil Emisi Gas Rumah Kaca di Indonesia}

Profil emisi GRK di Indonesia secara nasional dari tahun 2000 hingga tahun 2018 menunjukkan ada peningkatan yang fluktuatif dari tahun ke tahun (Gambar 3). Emisi GRK di Indonesia tahun 2018 mengalami kenaikan sebesar $60 \%$ dari tahun 2000. Kenaikan yang sangat signifikan tersebut diakibatkan oleh adanya peningkatan dalam penggunaan energi, selain itu adanya peningkatan dalam penggunaan lahan dan hutan serta kebakaran lahan terutama lahan gambut. Penggunaan energi dan penggunaan lahan serta hutan berkontribusi terbesar dalam sumbangan emisi GRK di Indonesia. Menurut data Laporan Inventarisasi Gas Rumah Kaca dan Monitoring, Pelaporan Verifikasi Tahun 2019 dari Ditjen Pengendalian Perubahan Iklim, Kementerian Lingkungan Hidup dan Kehutanan, gas rumah kaca dari sektor energi pada tahun 2018 sebesar 36,38\%, sedangkan sektor pertanian, kehutanan dan penggunaan lahan lainnya sebesar $44,82 \%$ dari total emisi gas rumah kaca yang dihasilkan di Indonesia.

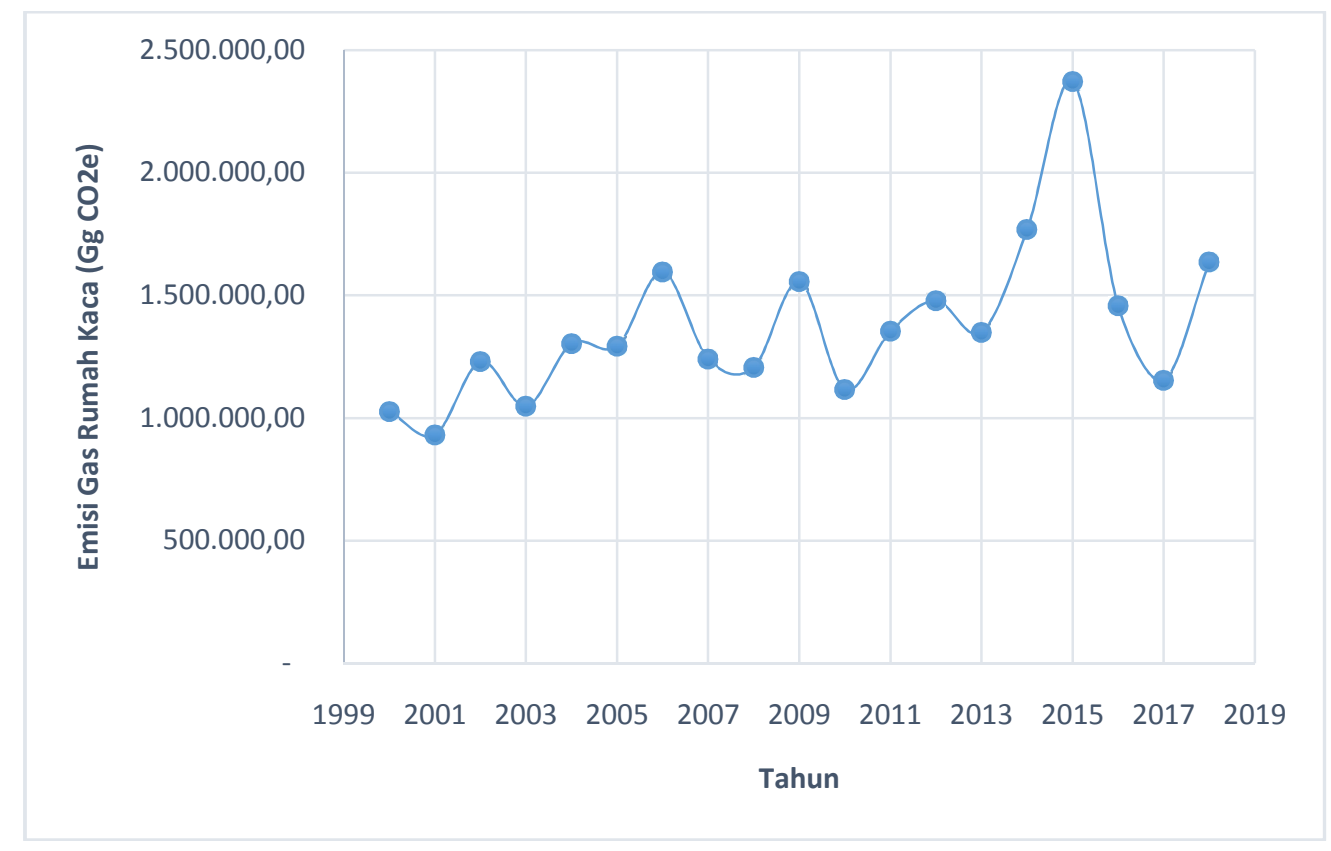

Gambar 3. Grafik Profil Emisi GRK Nasional Tahun 2000-2018 (Direktorat Jenderal Pengendalian Perubahan Iklim, Kementerian Lingkungan Hidup dan Kehutanan; 2020)

Emisi gas rumah kaca pada sektor energi, cakupan inventarisasinya meliputi kegiatan pengadaan atau penyediaan energi dan penggunaan energi. Pengadaan atau penyediaan energi terdiri dari kegiatan-kegiatan eksplorasi dan eksploitasi energi-energi primer (mintak mentah, batu bara); konversi energi primer menjadi energi sekunder dan kegiatan penyaluran dan distribusi energi. Kegiatan yang termasuk dalam penggunaan energi seperti penggunaan bahan bakar untuk peralatan tidak bergerak atau stasioner dan peralatan yang bergerak (transportasi).

Profil emisi GRK di Indonesia secara nasional dari tahun 2000 hingga tahun 2018 menunjukkan ada peningkatan yang fluktuatif dari tahun ke tahun. Emisi GRK di Indonesia tahun 2018 mengalami kenaikan sebesar $60 \%$ dari tahun 2000 . Kenaikan yang sangat signifikan tersebut diakibatkan oleh adanya peningkatan dalam penggunaan energi, selain itu adanya peningkatan dalam penggunaan lahan dan hutan serta kebakaran lahan terutama lahan gambut. Penggunaan energi dan pertanian, kehutanan dan penggunaan lahan lainnya berkontribusi terbesar dalam sumbangan emisi GRK di Indonesia. GRK dari sektor energi pada tahun 2018 sebesar 36,38\%, sedangkan sektor pertanian, kehutanan dan penggunaan lahan lainnya sebesar 52,23\% dari total emisi GRK yang dihasilkan di Indonesia. Emisi GRK di Indonesia mengalami nilai tertinggi pada emisi tahun 2015 yaitu sebesar 2.372.558,37 $\mathrm{Gg} \mathrm{CO}_{2} \mathrm{e}$ dan terendah pada emisi tahun 2001 dengan sebesar 932.052,11 $\mathrm{Gg} \mathrm{CO}_{2} \mathrm{e}$.

Inventarisasi GRK di Indonesia memerlukan suatu kelembagaan yang baik dengan tujuan untuk memfasilitasi proses dan meningkatkan kualitas inventarisasi GRK. Kelembagaan tersebut juga berperan penting dalam proses penjaminan dan pengendalian mutu (Quality Assurance dan Quality Control) penyelenggaraan inventarisasi GRK. Kelembagaan ini berasal dari lintas kementerian/lembaga pemerintah sesuai dengan sektor inventarisasi GRK. Sektor inventarisasi GRK di Indonesia terdiri dari 4 sektor yaitu 
sektor energi, sektor pertanian, kehutanan dan penggunaan lahan lainnya, sektor industri pengolahan dan penggunaan produk dan sektor limbah.

Kegiatan industri merupakan kegiatan yang juga menyumbang emisi GRK di atmosfer. Sumber emisi GRK pada kegiatan industri berasal dari 3 sektor yaitu sektor IPPU, sektor energi dan sektor limbah (Gambar 4). Emisi GRK dari sektor IPPU berasal dari berbagai jenis industri seperti industri mineral, industri kimia, industri logam, penggunaan produk bahan bakar non-energi dan pelarut, industri elektronik, penggunaan produk pengganti zat-zat yang menipis lapisan ozon, pembuatan produk-produk lainnya dan penggunaannya serta industri lain-lain seperti industri pulp dan kertas, industri makanan dan minuman. Emisi GRK dari sektor energi berasal dari pembakaran bahan bakar (fuel combustion) pada kategori industri manufaktur dan konstruksi (manufacturing industries and construction) dan emisi fugitive dari bahan bakar (fugitive emmissions from fuels). Sektor limbah menghasilkan emisi GRK yang berasal dari pengolahan limbah industri baik padat maupun cair.

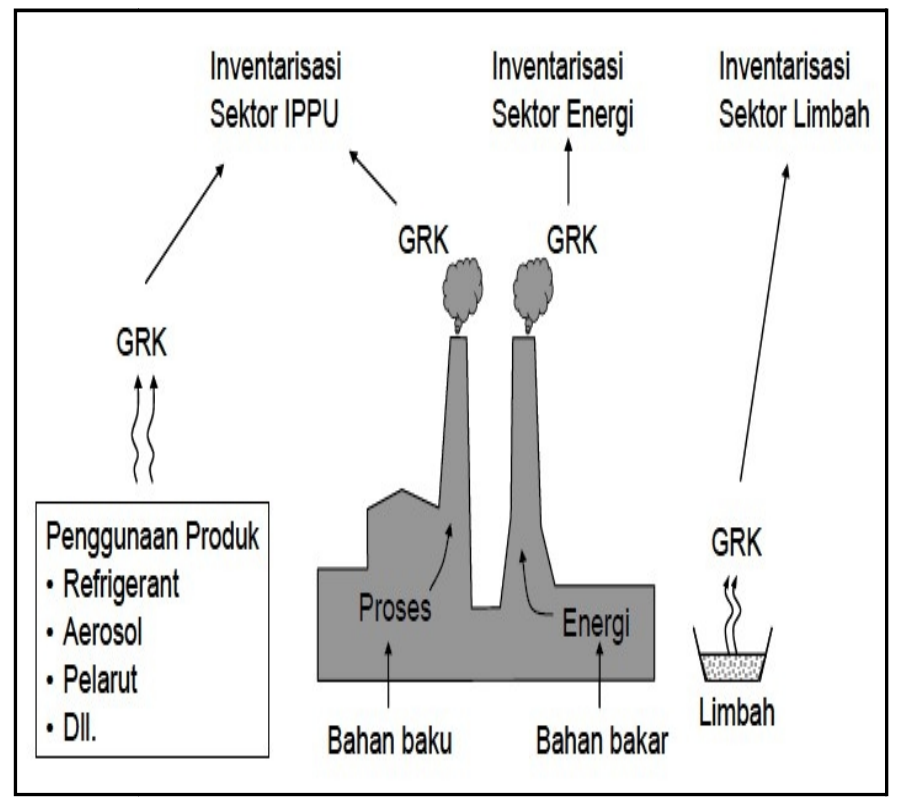

Gambar 4. Proses Emisi GRK pada Kegiatan Industri(Dewi, 2012)

Profil emisi GRK pada kegiatan industri di Indonesia didapatkan dengan mengolah data sekunder berupa data inventarisasi GRK pada sektor dan sub-sektor yang masuk sebagai kontributor emisi GRK kegiatan industri ke atmosfer Indonesia. Data yang diolah menggunakan data dari tahun 2010 sampai 2018. Pengambilan data pada rentang tahun tersebut bertujuan untuk menjawab tujuan dari penelitian ini yaitu mengetahui pengaruh penerapan konsep industri hijau terhadap emisi GRK kegiatan industri. Penerapan konsep industri hijau secara masif dilakukan sejak tahun 2010. Oleh karena itu pengambilan data perlu dilakukan batasan pada rentang tahun 2010 sampai 2018. Adapun data emisi GRK kegiatan industri di Indonesia hasil pengolahan dapat dilihat pada Tabel 1.

Tabel 1. Profil Emisi GRK Kegiatan Industri di Indonesia Tahun 2010-2018

\begin{tabular}{lcllc}
\hline Tahun & $\begin{array}{l}\text { Emisi Sektor } \\
\text { Energi (Gg CO2e) }\end{array}$ & $\begin{array}{l}\text { Emisi Sektor } \\
\text { IPPU (Gg CO3e) }\end{array}$ & $\begin{array}{l}\text { Emisi Sektor } \\
\text { Limbah (Gg CO3e) }\end{array}$ & $\begin{array}{l}\text { Total Emisi GRK } \\
\text { Kegiatan Industri } \\
\text { (Gg CO2e) }\end{array}$ \\
$\mathbf{2 0 1 0}$ & 155.848 & $36.032,83$ & $35.284,29$ & $227.165,12$ \\
$\mathbf{2 0 1 1}$ & 171.999 & $35.910,40$ & $37.760,86$ & $245.670,26$ \\
$\mathbf{2 0 1 2}$ & 164.877 & $40.077,58$ & $39.820,38$ & $244.774,96$ \\
$\mathbf{2 0 1 3}$ & 114.010 & $39.109,53$ & $42.349,75$ & $195.469,28$ \\
$\mathbf{2 0 1 4}$ & 117.830 & $47.488,95$ & $43.166,14$ & $208.485,09$ \\
$\mathbf{2 0 1 5}$ & 129.451 & $49.297,37$ & $44.802,13$ & $223.550,50$ \\
$\mathbf{2 0 1 6}$ & 109.834 & $55.307,45$ & $49.332,09$ & $214.473,54$ \\
$\mathbf{2 0 1 7}$ & 109.833 & $55.394,51$ & $55.261,57$ & $220.489,08$ \\
$\mathbf{2 0 1 8}$ & 126.879 & $59.262,00$ & $60.699,39$ & $246.840,39$ \\
\hline
\end{tabular}




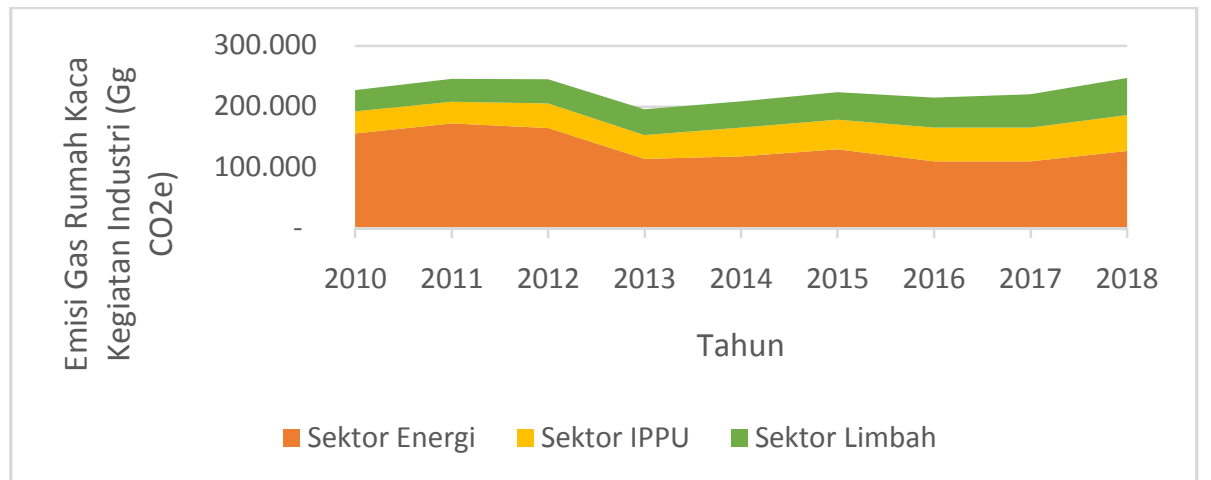

Gambar 5. Profil Emisi GRK Kegiatan Industri Berdasarkan Sektor Tahun 2010-2018

Dari data emisi GRK kegiatan industri pada Tabel 1 dan interpretasi data dalam bentuk grafik pada Gambar 5 dapat dilihat bahwa emisi dari sektor energi mendominasi terhadap emisi GRK kegiatan industri dengan persentase rata-rata sebesar $60 \%$. Emisi GRK dari sektor IPPU dan sektor limbah memiliki proporsi yang seimbang. Hal ini menunjukkan bahwa penggunaan energi pada kegiatan industri cukup besar dan sangat berpotensi menghasilkan emisi GRK ke atmosfer bumi. Penggunaan energi fosil seperti minyak bumi dan batu bara serta listrik menjadi dominasi dalam proses produksi pada industri. Power plant untuk listrik di Indonesia yang masih didominasi dengan pembangkit listrik tenaga uap yang menggunakan batu bara juga menjadi kontributor yang menyumbangkan emisi GRK cukup besar. Konsumsi energi pada kegiatan industri dihitung dari seluruh energi yang dibutuhkan untuk memproduksi 1 unit produk. Termasuk didalamnya adalah konsumsi energi oleh transportasi barang/bahan baku yang digunakan secara internal di area produksi untuk menghasilkan produk.

Dalam proses industri terdapat energi yang tidak digunakan dalam proses industri, tetapi sebagai bahan baku industri (feedstock) atau istilahnya non-energy use of fuels. Bahan bakar atau energi tersebut tidak dihitung sebagai bagian dari konsumsi energi di industri, tetapi masuk pada sektor IPPU. Sektor IPPU dinilai kurang signifikan dibandingkan sektor energi dalam jumlah emisi GRK yang dihasilkannya. Kondisi ini diyakini akan berubah dengan adanya pertumbuhan ekonomi berbasis industri. Sumber emisi GRK pada sektor IPPU terbagi dalam 2 bentuk yaitu proses industri yang secara kimiawi atau fisik mengubah bahan dan penggunaan GRK itu sendiri untuk berbagai tujuan seperti lemari pendingin dan kaleng aerosol. Selain emisi GRK dari sektor IPPU yang tidak signifikan nilainya dibanding nilai emisi GRK dari sektor energi yaitu emisi GRK dari sektor limbah. Limbah merupakan hasil sampingan yang selalu ada pada setiap proses produksi suatu industri. Teknologi pengolahan limbah baik limbah cair, padat, gas dan B3 (bahan berbahaya dan beracun) yang telah banyak diaplikasi oleh industri-industri dapat menjadi nilai lebih dari limbah tersebut, bahkan dapat menjadi bahan baku untuk industri yang lainnya.

Besaran kontribusi emisi GRK pada kegiatan industri di Indonesia dengan rentang waktu antara tahun 2010-2018 memiliki rata-rata sebesar 225.213,14 $\mathrm{Gg} \mathrm{CO}_{2} \mathrm{e}$ atau $15,52 \%$ dari total emisi GRK secara nasional pada rentang tahun 2010-2018. Emisi GRK pada kegiatan industri dengan kontribusi terendah terjadi pada tahun 2013 yang sebesar 195.469,28 Gg CO 2 e atau sekitar 14,48\% dari total emisi GRK di Indonesia tahun 2013. Sedangkan emisi GRK pada kegiatan industri dengan kontribusi tertinggi terjadi pada tahun 2018 yang mencapai sebesar 246.840,39 $\mathrm{Gg} \mathrm{CO}_{2} \mathrm{e}$ atau 15,08\% dari total emisi GRK di Indonesia tahun 2018.

\section{Hubungan antara Penerapan Industri Hijau dan Emisi Gas Rumah Kaca Kegiatan Industri di Indonesia}

Hasil interpretasi data grafik pada Gambar 6 menunjukkan bahwa terdapat hubungan yang cenderung linier antar variabelnya. Linier positif terlihat pada grafik 6 (c) (jumlah industri penerima PIH terhadap emisi GRK kegiatan industri dari sektor IPPU) dan 6 (d) (jumlah industri penerima PIH terhadap emisi GRK kegiatan industri dari sektor limbah), sedangkan linier negatif Nampak pada grafik 6 (a) (jumlah industri penerima PIH terhadap emisi GRK kegiatan industri total) dan 6 (b) (jumlah industri penerima PIH terhadap emisi GRK kegiatan industri dari sektor energi). Linier positif pada grafik menunjukkan bahwa jumlah industri penerima PIH yang semakin meningkat dapat menyebabkan peningkatan emisi GRK, sedangkan linier negatif pada grafik menunjukkan bahwa peningkatan jumlah industri penerima PIH dapat menurunkan emisi GRK. Langkah selanjutnya yaitu uji normalitas untuk mengetahui data apakah terdistribusi normal atau tidak dengan menggunakan nilai Sig. (p-value) pada Kolmogorov-Smirnov dan Shapiro-Wilk. Dari hasil perhitungan dengan menggunakan pengangkat lunak IBM SPSS Statistics 25 didapatkan hasil seperti dalam Tabel 2. 


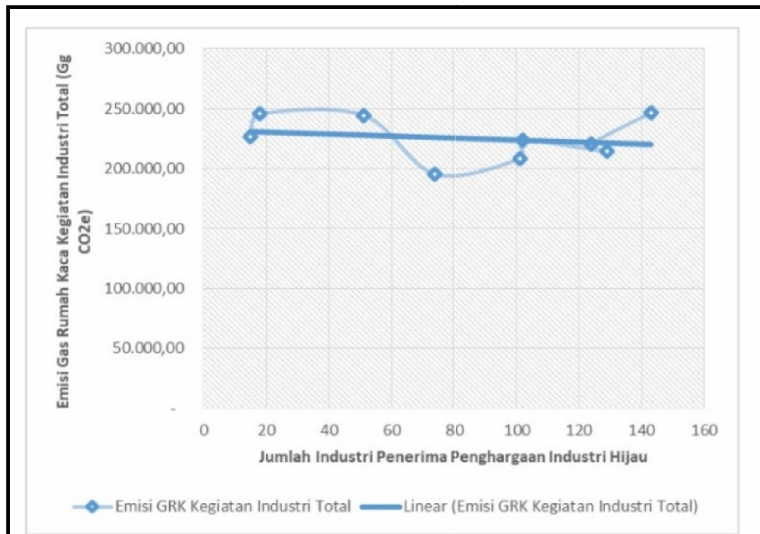

(a)

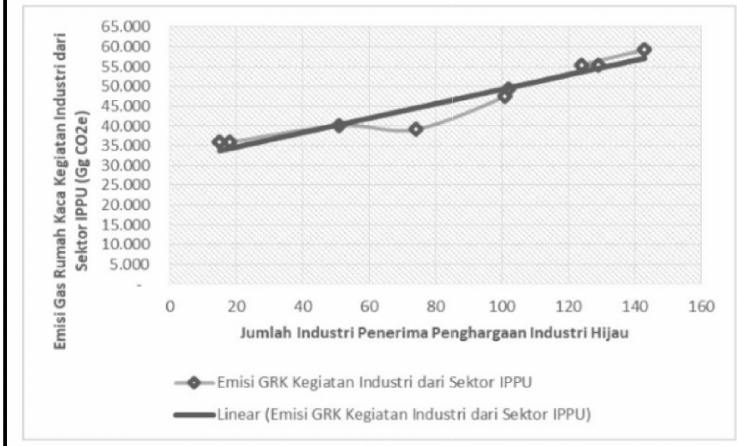

(c)

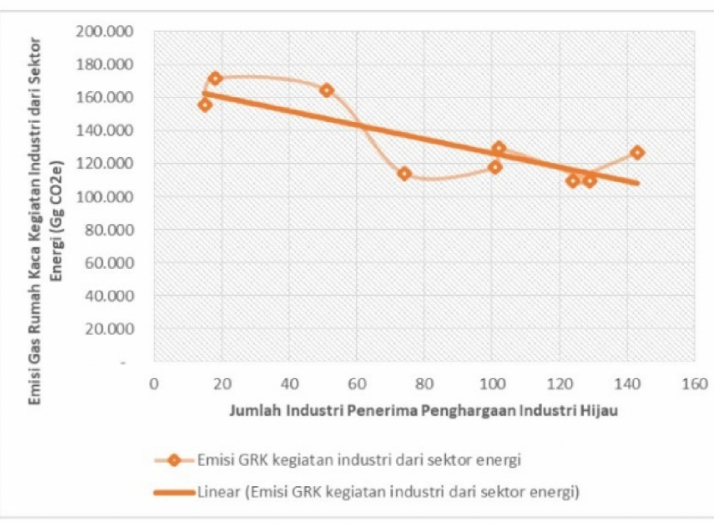

(b)

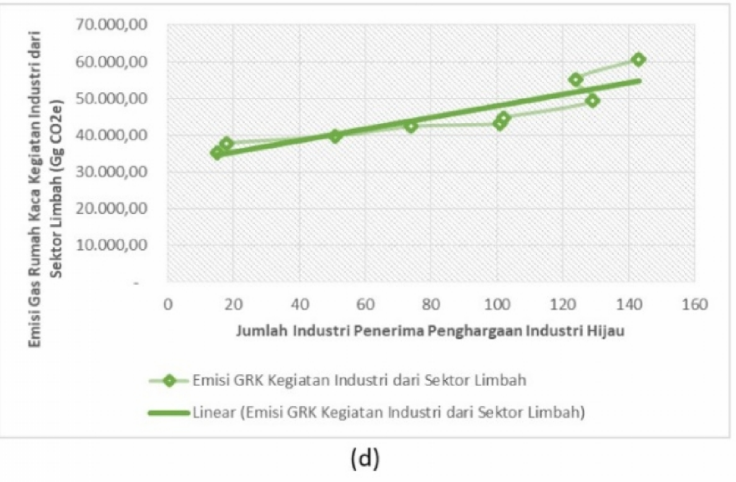

(d)

Gambar 6. Grafik Jumlah Industri Penerima PIH terhadap Emisi GRK Kegiatan Industri

Keterangan: Grafik (a) Emisi GRK Kegiatan Industri Total; (b) Emisi GRK Kegiatan Industri dari Sektor Energi; (c) Emisi GRK Kegiatan Industri dari Sektor IPPU; dan (d) Emisi GRK Kegiatan Industri dari Sektor Limbah

Tabel 2. Uji Normalitas

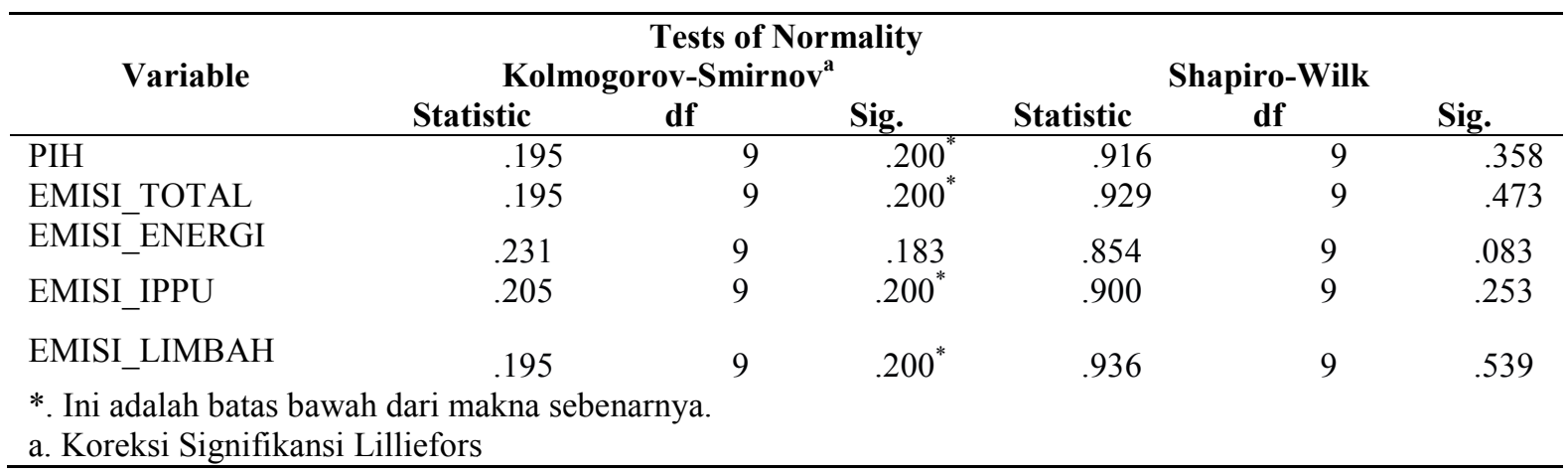

Nilai Sig. (p-value) dari semua variabel pada Kolmogorov-Smirnov dan Shapiro-Wilk hasilnya menunjukkan lebih dari 0,05 sehingga data pada semua variabel terdistribusi normal dan langkah analisis dapat dilanjutkan. Langkah selanjutnya yaitu perhitungan nilai koefisien korelasinya (r), koefisien determinasi (R), $\mathrm{r}$ tabel kritis, t-hitung dan $\mathrm{t}$-tabel. Hasil pengolahan data menggunakan pengangkat lunak IBM SPSS Statistics 25 ditunjukkan pada Tabel 3.

Nilai koefisien korelasinya (r) untuk variabel jumlah industri penerima PIH dan emisi GRK kegiatan industri total memiliki koefisien korelasi (r) sebesar $-0,226$. Nilai tersebut menunjukkan bahwa korelasi yang terjadi antara variabel bersifat lemah dan berlawanan arah. Nilai koefisien korelasinya (r) untuk variabel jumlah industri penerima PIH dan emisi GRK kegiatan industri dari sektor energi memiliki koefisien korelasi (r) sebesar $-0,826$. Nilai tersebut menunjukkan bahwa korelasi yang terjadi antara variabel bersifat kuat dan berlawanan arah. Nilai koefisien korelasinya (r) untuk variabel jumlah industri penerima PIH dan emisi 
GRK kegiatan industri dari sektor IPPU memiliki koefisien korelasi (r) sebesar 0,961. Nilai tersebut menunjukkan bahwa korelasi yang terjadi antara variabel bersifat kuat dan searah. Nilai koefisien korelasinya (r) untuk variabel jumlah industri penerima PIH dan emisi GRK kegiatan industri dari sektor limbah memiliki koefisien korelasi (r) sebesar 0,900. Nilai tersebut menunjukkan bahwa korelasi yang terjadi antara variabel bersifat kuat dan searah.

Tabel 3. Nilai koefisien korelasinya (r), koefisien determinasi (R), $r$ tabel kritis, t-hitung dan t-tabel

\begin{tabular}{|c|c|c|c|c|c|c|}
\hline Independen & $\begin{array}{l}\text { Variabel } \\
\text { Dependen }\end{array}$ & $\begin{array}{l}\text { Koefisien } \\
\text { Korelasi } \\
\text { Pearson (r) }\end{array}$ & $\begin{array}{l}\text { Koefisien } \\
\text { Determinasi } \\
\left(\mathbf{R}=\mathbf{r}^{2}\right)\end{array}$ & $\begin{array}{l}\text { r tabel } \\
\text { kritis }\end{array}$ & t-hitung & $\begin{array}{l}\text { t-tabel } \\
(\alpha)=5 \% \\
d b=n-2 \\
n=9\end{array}$ \\
\hline \multirow{4}{*}{$\begin{array}{l}\text { Jumlah } \\
\text { industri } \\
\text { penerima } \\
\text { PIH }\end{array}$} & $\begin{array}{l}\text { Emisi GRK kegiatan } \\
\text { industri total }\end{array}$ & $-0,226$ & 0,051 & \multirow[t]{4}{*}{0,666} & $-0,614$ & \multirow[t]{4}{*}{2,365} \\
\hline & $\begin{array}{l}\text { Emisi GRK kegiatan } \\
\text { industri dari sektor } \\
\text { energi }\end{array}$ & $-0,826$ & 0,682 & & $-3,877$ & \\
\hline & $\begin{array}{l}\text { Emisi GRK kegiatan } \\
\text { industri dari sektor } \\
\text { IPPU }\end{array}$ & 0,961 & 0,924 & & 9,194 & \\
\hline & $\begin{array}{l}\text { Emisi GRK kegiatan } \\
\text { industri dari sektor } \\
\text { limbah }\end{array}$ & 0,900 & 0,810 & & 5,463 & \\
\hline
\end{tabular}

Langkah selanjutnya dalam analisis korelasi bivariate Pearson yaitu menyimpulkan keputusan hasil analisis. Langkah ini dengan melakukan uji hipotesa yang dilakukan dengan dua cara yaitu dengan melihat nilai mutlak t-hitung dan t-tabel serta nilai mutlak $\mathrm{r}$ hitung dan $\mathrm{r}$ tabel kritis. Variabel independen dan dependen memiliki hubungan yang linier jika nilai mutlak t-hitung lebih besar dari t-tabelnya atau nilai mutlak $r$ hitung lebih besar dari nilai $r$ tabel kritis. Dari hasil perhitungan pada tabel di atas dapat dilihat bahwa variabel independen (jumlah industri penerima PIH) memiliki hubungan linier dengan 3 variabel dependen (emisi GRK kegiatan industri dari sektor energi, IPPU dan limbah). Sedangkan dengan variabel dependen (emisi GRK kegiatan industri total) tidak terdapat hubungan yang linier.

Nilai koefisien determinasi (R) menyatakan proporsi keragaman yang dapat diterangkan/dijelaskan oleh hubungan linier antara variabel independen dan dependen. Berdasarkan hasil analisis dengan tingkat kepercayaan 95\% dapat disimpulkan bahwa terdapat sekitar 5,1\% variasi tinggi rendahnya emisi GRK kegiatan industri total ditentukan oleh jumlah industri penerima PIH. Variasi tinggi rendahnya emisi GRK kegiatan industri dari sektor energi dipengaruhi oleh jumlah industri penerima PIH dengan pengaruh sebesar $68,2 \%$, sedangkan variasi tinggi rendahnya emisi GRK kegiatan industri dari sektor IPPU dipengaruhi sebesar 92,4\% oleh jumlah industri penerima PIH. Variasi tinggi rendahnya emisi GRK kegiatan industri dari sektor limbah mendapat pengaruh sebesar $81 \%$ dari jumlah industri penerima PIH.

Hasil analisis data juga menunjukkan bahwa dengan adanya peningkatan jumlah industri yang menerima PIH ternyata cenderung meningkatkan emisi GRK kegiatan industri pada sektor IPPU dan limbah. Peningkatan emisi GRK kegiatan industri pada sektor IPPU kemungkinan diakibatkan oleh adanya penggunaan bahan-bahan penolong dalam kegiatan industri seperti bahan-bahan kimia yang tidak ada bahan substitusi yang rendah emisi sehingga emisi GRK dari sektor IPPU mengalami peningkatan. Selalin itu juga adanya kemungkinan industri-industri yang menggunakan bahan-bahan kimia belum optimal dalam menerapkan konsep industri hijau dalam proses produksinya. Sedangkan pada sektor limbah, emisi GRK kegiatan industri mengalami peningkatan kemungkinan diakibatkan oleh belum adanya pengolahan limbah yang optimal terutama industri-industri yang belum maksimal dalam menerapkan konsep industri hijau. Oleh karena itu limbah masih hanya sekedar sebagai hasil buangan industri yang berpotensi dalam menyumbang emisi GRK ke lingkungan.

\section{SIMPULAN}

Penelitian ini menunjukkan bahwa profil emisi gas rumah kaca di Indonesia menunjukkan selalu mengalami kenaikan setiap tahunnya. Hal yang sama juga terjadi pada emisi gas rumah kaca pada kegiatan industri yang mengalami kenaikan dari tahun ke tahun. Kenaikan ini seiring dengan perkembangan ekonomi yang bergeser dari ekonomi agraris menjadi ekonomi industri. Kegiatan industri yang merupakan salah satu 
sumber penghasil gas rumah kaca sangat perlu melakukan mitigasi terhadap peningkatan emisi gas rumah kaca dari kegiatan industri. Salah satu mitigasi yang dilakukan yaitu dengan penerapan konsep industri hijau. Penerapan industri hijau di Indonesia semakin meningkat dengan semakin aktifnya industri-industri menerapkan konsep industri hijau pada industrinya dan semakin meningkat tingkat partisipasi industri dalam program PIH. Program PIH juga memberikan keuntungan melalui adanya penghematan industri dalam pemakaian energi dan air.

Penelitian ini juga menunjukkan bahwa penerapan konsep industri hijau di Indonesia melalui program PIH masih belum memberikan pengaruh yang signifikan terhadap profil emisi gas rumah kaca pada kegiatan industri. Penerapan industri hijau melalui PIH memiliki pengaruh yang kecil $(5,1 \%)$ terhadap penurunan emisi GRK total kegiatan industri. Emisi GRK sektor energi manufaktur mengalami penurunan yang dipegaruhi oleh penerapan industri hijau melalui program PIH dengan nilai pengaruh sebesar $68,2 \%$. Pengaruh yang berlawanan terjadi pada sektor IPPU (Industrial Processes and Product Use) dan limbah. Penerapan industri hijau melalui program PIH meningkatkan emisi GRK sektor IPPU dengan pengaruh sebesar 92,4\%, sedangkan berpengaruh sebesar $81 \%$ dalam peningkatan emisi GRK sektor limbah. Perlu adanya peningkatan keikutsertaan industri dalam penerapan industri hijau melalui PIH yang sebelumnya bersifat sukarela (voluntary) menjadi wajib (mandatory). Sehingga penerapan industri hijau dapat menjadi program mitigasi perubahan iklim yang lebih efektif.

\section{REFERENSI}

Aminah and Yusriyadi, 2018. Implementasi Program Industri Hijau Dalam Rangka Kebijakan Penurunan Emisi Gas Rumah Kaca, Bina Hukum Lingkungan, 3(1), pp. 63-80.

Anggraeni, D. Y., 2015. Pengungkapan Emisi Gas Rumah Kaca, Kinerja Lingkungan dan Nilai Perusahaan, Jurnal Akuntansi dan Keuangan Indonesia, 12(2), pp. 188-209.

Baiquni, M., 2009. Revolusi Industri, Ledakan Penduduk dan Masalah Lingkungan, Jurnal Sains \&Teknologi Lingkungan, 1(1), pp. 38-59.

Cahyono, W. E., 2007. Pengaruh Pemanasan Global terhadap Lingkungan Bumi, Berita Dirgantara LAPAN, $8(2)$, pp. 28-31.

Dewi, R. G., 2012.Memperkirakan Tingkat Emisi GRK dari Proses Industri dan Penggunaan Produk (IPPU). Bandung.

Indonesia, P. R., 2014.Undang-Undang No 3 tahun 2014 Tentang Perindustrian.

Karyono, T. H., 2007. Pemanasan Bumi dan Tanggung Jawab Arsitek, Seminar Pemanasan Bumi, pp. 1-13.

Kementerian Lingkungan Hidup dan Kehutanan, 2019.Laporan Inventarisasi Gas Rumah Kaca dan Monitoring, Pelaporan Verifikasi Tahun 2018.

Kusminingrum, N.,2008. Potensi Tanaman dalam Menyerap CO2 dan CO untuk Mengurangi Dampak Pemanasan Global, Jurnal Permukiman, 3(2), pp. 96-105.

Latuconsina, H., 2010. Dampak Pemanasan Global terhadap Ekosistem Pesisir dan Lautan, Jurnal Ilmiah Agribisnis dan Perikanan, 3(1), pp. 30-37.

Muryani, 2018. Produksi bersih dan Model Kerjasama sebagai Upaya Mtigasi Emisi Gas Rumah Kaca pada Sektor Industri, Jurnal Dialektika, 13(1), pp. 48-65.

SOS, T., 2011.Pemanasan Global, Solusi dan Peluang Bisnis. Jakarta: Gramedia Pustaka Utama.

Sugiyono, 2018. Metode Penelitian Kombinasi. Bandung: Penerbit Alfabeta.

Sugiyono, A., 2006. Penanggulangan Pemanasan Global di Sektor Pengguna Energi, Jurnal Sains \& Teknologi Modifikasi Cuaca, 7(2), pp. 15-19.

Suwedi, N., 2005. Upaya Pencegahan dan Penanggulangan Dampak Pemanasan Global, Jurnal Teknologi Lingkungan, 6(2), pp. 397-401.

Triana, V., 2008. Pemanasan Global, Jurnal Kesehatan Masyarakat Andalas, 2(2), pp. 159-163.

Waryono, T., 2008. Upaya Pemberdayaan Masyarakat dalam Pelestarian Hutan sebagai Pencegah Pemanasan Global, Kumpulan Makalah 1987-2008, pp. 1-9. 